\section{Syngenta ends plant-research deal with Berkeley}

Rex Dalton, San Diego

An industrial-academic partnership on plant research that rocked the University of California (UC), Berkeley, when it started five years ago is quietly coming to an end.

The deal, under which Syngenta, the Swiss agricultural biotechnology firm, provided $\$ 25$ million to the university's department of plant and microbial biology, will expire on 23 November, after the company declined to exercise its option to continue it. The deal was originally drawn up by Novartis, which spun off its agricultural interest in 2000 to form Syngenta.

"There is a shift in how we do discovery research," says plant biologist Simon Bright, head of technology interaction for Syngenta at Jealott's Hill, Berkshire, UK. "We are focusing on moving discoveries in the pipeline to products."

UC Berkeley officials say that they are unsurprised, but that they would have liked to renew the agreement. "It funded a lot of blue-sky research that would not otherwise have taken place," says political scientist Robert Price, UC Berkeley's associate vice-chancellor for research.

Early next year, an independent analysis of the partnership's impact is to be completed by a research team from Michigan State University (MSU) in Lansing. The $\$ 225,000$ study - run by sociologist Lawrence Busch of MSU's

Institute of Food and Agricultural Standards - was commissioned by the UC Berkeley academic senate.

When the Syngenta pact was revealed five years ago, it caused a fierce argument about relationships between industry and university departments (see Nature 399, 5; 1999). It gave faculty and students access to dynamic technologies, such as proprietary plant sequence databases, but allowed the corporation to keep rights to discoveries.

UC Berkeley officials say that

Syngenta reviewed some 375 abstracts of scientific research undertaken by faculty members and students. Preliminary discussions have been held about the corporation licensing one undisclosed discovery for development, officials say. Plant pathologist Brian Staskawicz, the UC Berkeley professor who supervised the deal, says: "I think everyone would agree the collaboration was a great success. It really was an experiment." Other faculty members say that they will await the results of the outside analysis before commenting.

\section{Academy calls for improved tests to beat prion disease}

Jonathan Knight, San Francisco

Diagnostic tests for prion diseases need a "quantum leap" in sensitivity if they are to help prevent future outbreaks, says a report from the US National Academy of Sciences.

Basic research into the nature of prions, which cause illnesses such as bovine spongiform encephalopathy (or mad cow disease), will be essential to achieve this, says the report. It was commissioned by the Department of Defense and prepared by a panel chaired by Richard Johnson, professor of neurology at Johns Hopkins University School of Medicine in Baltimore, Maryland.

"We need a fundamentally different approach," says Johnson. "Incremental improvements in existing tests are not going to do it." Prion diseases, or transmissible spongiform encephalopathies (TSEs), can only be confirmed after death and even then can be missed. A test is needed that can spot the smallest amount of infectious prion protein that can cause disease, the report says. This would require a sensitivity at least 1,000 times greater than that of current tests.

One possible approach would be to work out the three-dimensional structure of the prion protein, so that a compound could be designed to target it. This has been complicated by the insolubility of prion proteins.

Fred Cohen, a prion researcher at the University of California, San Francisco,

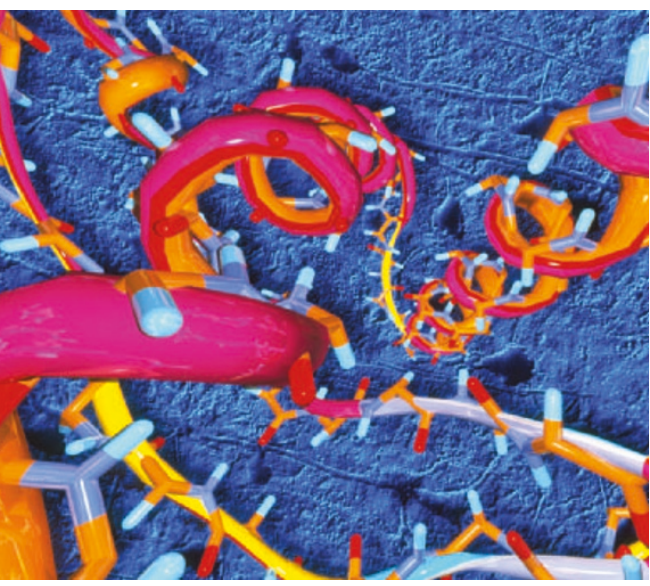

Knotty problem: the prion's insolubility slows research. welcomes the report. "It was a good group of people to probe these questions," he says. Although there has been an epidemic of TSE among elk and deer in the Midwest, there is no mad cow disease in the United States, and Cohen doubts whether the political will exists to fund the work.

Congress handed a major role in prion research to the defence department last year, when it authorized the National Prion Research Program. This distributed US\$42 million in research grants in 2002 and may win further funds in 2004. Part of the military's interest concerns its troops abroad, who may have been exposed to mad cow disease. Prion diseases are also a potential bioterror agent. www.nap.edu

\title{
UK considers plans to shake up clinical trials
}

\section{Jim Giles, London}

An ambitious proposal was made this week to reinvigorate clinical trials in the United Kingdom. And the government looks likely to implement it, at least in some form, in a bid to strengthen Britain's biotechnology and pharmaceutical industries.

The plan would set up a National Clinical Trials Agency with an annual budget of $£ 150$ million (US\$250 million). The agency would fund clinical research and advise pharmaceutical companies on the conduct and regulation of clinical trials. It would also help the National Health Service (NHS), which runs most British hospitals, to find patients to take part.

The report from the Bioscience Innovation and Growth Team - made up of some 70 researchers, industry representatives and government officials - was released on 17
November. It recommends boosting funds for research and development in the NHS from $0.9 \%$ (currently $\mathfrak{E} 560$ million) of its total budget to $1.5 \%$. The report also suggests creating 100 places a year on degree courses that would combine medicine and research, similar to MD-PhD degrees in the United States.

The government is to respond within six months. But team members are confident: Tony Blair, the prime minister, has repeatedly pledged support for the bioscience industry.

Some of the group's plans may prove too controversial to implement, however. It suggests reducing from 20 to 3 the number of protesters required for the police to put restrictions on an animal-rights demonstration. Science minister David Sainsbury says he doesn't see an immediate need for this. www.bioindustry.org/bigtreport 